\title{
Anthropometric and biochemical parameters in older women with \\ a history of gestational diabetes
}

\author{
Senay Topsakal ${ }^{1}$, Fulya Akin ${ }^{2}$, Guzin F. Yaylali ${ }^{2}$
}

${ }^{1}$ Department of Endocrinology and Metabolism, Burdur State Hospital, Yeni Mahalle, Burdur, 15030, Turkey

\section{${ }^{2}$ Department of Endocrinology and Metabolism, Faculty of Medicine, Pamukkale University, Kinikli Campus, Denizli, 20070, Turkey}

\section{INTRODUCTION}

Gestational diabetes mellitus (GDM) is defined by glucose intolerance of variable severity with onset of first recognition during pregnancy (WHO, 2012). Hyperglycaemia during pregnancy is found to be associated with various maternal and perinatal adverse outcomes (HAPO, 2008; Landon et al., 2011). GDM is a condition that occurs during pregnancy when the body cannot produce enough insulin to handle the effects of a growing baby and changing hormone levels. Numerous studies reported that an increased risk of GDM among women who are overweight or obese compared with lean or normal-weight women

The purpose of this study is to compare anthropometric and biochemical parameters in postmenopausal women with a history of GDM and controls

\section{MATERIAL AND METHODS}

Subjects were 28 overweight/obese, postmenopausal and sedentary women who had a history of GDM and 27 postmenopausal without a history of GDM as healthy postmenopausal controls. All subjects were recruited to be overweight and obese (BMI $>25 \mathrm{~kg} / \mathrm{m} 2$, range $25-40 \mathrm{~kg} / \mathrm{m} 2$ ) women. Only women who were weight stable $(<2.0 \mathrm{~kg}$ weight change in past year) and sedentary $(<20 \mathrm{~min}$ of aerobic exercise $2 \mathrm{x} /$ week) were recruited. The individuals aged 40-52 years referred to the Department of Endocrinology and Metabolic Diseases. The study protocol was approved by the Ethical Committee of Pamukkale University. Written informed consent was obtained from all of the subjects and/or their parents or legal guardians before participation in the study. Height and weight were measured in light clothing without shoes. Body height was measured using a statometer and body weight was measured using a digital electronic weighing scale. Body mass index (BMI) was calculated as weight in kilograms divided by the square of height in meters. Waist circumference was measured using a flexible measuring tape, midway between the xiphoid and the umbilicus during the mid-inspiratory phase. Anthropometric measurements were carried out three times by a single tester. Body water and fat distribution were assessed by multiple frequency bioelectric impedance measurement with a portable impedance analyzer (Tanita, Tokyo, Japan). The average was taken of two values of blood pressure measured 2-3 min apart with the subject in the sitting position after resting for at least $15 \mathrm{~min}$. Serum levels of fasting and postprandial glucose, total cholesterol, triglyceride, high-density lipoprotein cholesterol, low-density lipoprotein cholesterol, and uric acid were analyzed with commercial kits (Beckman-Coulter, Pasadena, CA, USA) in an LX-20 autoanalyzer (Beckman-Coulter). The levels of serum insulin, thyroid-stimulating hormone, and DHEAS were determined in an Immulite 2000 immunoanalyzer (Siemens, Erlangen, Germany).

Descriptive statistics, proportions for categorical variables, and means and standard deviations for continuous variables were used to describe the study groups. Comparisons between obese male and female groups were analyzed using a Student's t test. A one-way analysis of variance was performed to evaluate the findings, as well as to perform statistical comparisons between the male and female groups. Significance assessment was carried out by the Duncan test. The results were expressed as mean \pm standard deviation. The values were considered to be statistically significant when $\mathrm{P}<0.05$. All statistical analysis was done using SPSS v 13.0 (SPSS Inc., Chicago, IL, USA).

\section{RESULTS:}

We observed significantly higher Albumin, Prospandial insulin, Anti-throglobulin antibody and GGT levels in patient with gestational diabetes while decreased FSH, LH and Thyroglobulin levels. We couldn't find any differences in fasting glucose, BMI, WHR, TSH and ALT levels. This study supported that GDM is a predisposing factor for DM after menopause. Physical characteristics, total and regional body composition of overweight, sedentary women with a history of GDM and controls are shown in Table 1 .

\section{DISCUSSION:}

Women with a history of GDM are at an increased risk for the development of type 2 diabetes mellitus (T2DM) within 5 years following pregnancy (Metzger et al., 1993; Kaufmann et al., 1995) with the reported incidence of T2DM ranging from almost $3 \%$ to $>70 \%$ in studies on women examined between 6 and 28 weeks post partum (Kim et al., 2007). Younger and more physically fit, premenopausal women with prior GDM display similar central obesity, glucose, and metabolic profiles as postmenopausal controls. Postmenopausal women with prior GDM are more insulin resistant than controls of similar age, adiposity, and fitness levels and display comparable glucose utilization rates as similar as women with T2DM suggesting that a prior history of GDM may be an early manifestation of increased risk of later T2DM (Ryan et al., 2013). Although the majority of women with GDM will be normoglycemic in the immediate postpartum period, studies suggest that $11 \%$ to $33 \%$ will display evidence of impaired glucose tolerance, and $1 \%$ to $8 \%$ will have diabetes, at 6 to 12 weeks postdelivery (Lawrence et al., 2010). In many cases, these individuals likely had some degree of glucose intolerance, pre-diabetes or even undiagnosed T2D, that preceded the pregnancy, but their condition was not recognized until the postpartum screen. Even when postpartum glucose levels are within normal limits, women with a history of GDM are at much higher risk of developing GDM in subsequent pregnancies (Getahun et al., 2010).Our study results showed that GMD is predisposing factor in older women.
Table 1: Baseline and demographic characteristics of obese patients with history of GDM and control group

\begin{tabular}{|c|c|c|c|}
\hline & Control $(\mathrm{n}=27)$ & \begin{tabular}{|l|} 
Patient with \\
GDM history \\
$(\mathrm{n}=28)$
\end{tabular} & $\mathrm{P}$ \\
\hline Ages (Years) & $45.44 \pm 7.02$ & $40.96 \pm 6.80$ & $>0.05$ \\
\hline Height $(\mathrm{cm})$ & $154.59 \pm 6.86$ & $157.82 \pm 5.15$ & $>0.05$ \\
\hline Weight $(\mathrm{kg})$ & $83.53 \pm 14.70$ & $88.16 \pm 13.85$ & $>0.05$ \\
\hline BMI $\left(\mathrm{kg} / \mathrm{m}^{2}\right)$ & $34.27 \pm 5.55$ & $35.45+5.78$ & $>0.05$ \\
\hline Waist circumference $(\mathrm{cm})$ & $96.81 \pm 9.55$ & $98.23 \pm 10.23$ & $>0.05$ \\
\hline Hip circumference $(\mathrm{cm})$ & $110.75 \pm 7.12$ & $114.14 \pm 9.32$ & $>0.05$ \\
\hline Waist hip ratio(cm) & $0.86 \pm 0.07$ & $0.85 \pm 0.09$ & $>0.05$ \\
\hline Fasting blood glucose $(\mathrm{mg} / \mathrm{dl})$ & $109.11 \pm 35.26$ & $101.92 \pm 13.21$ & $>0.05$ \\
\hline Postprandial blood glucose (mg/dl) & $118.13 \pm 63.46$ & $117.77 \pm 27.61$ & $>0.05$ \\
\hline SGOT (IU/l) & $19.07 \pm 7.12$ & $17.25 \pm 3.53$ & $>0.05$ \\
\hline SGPT (IU/) & $18.53 \pm 8.51$ & $20.60 \pm 11.96$ & $>0.05$ \\
\hline ALP (IU/l) & $78.96 \pm 20.78$ & $72.57 \pm 19.68$ & $>0.05$ \\
\hline ALB (gr/dl) & $4.55 \pm 0.23$ & $6.27 \pm 8.96$ & $<0.05^{*}$ \\
\hline $\mathrm{Ca}(\mathrm{mg} / \mathrm{dl})$ & $9.38 \pm 0.43$ & $9.25 \pm 0.39$ & $>0.05$ \\
\hline $\mathrm{P}(\mathrm{mg} / \mathrm{dl})$ & $3.59 \pm 0.57$ & $3.53 \pm 0.49$ & $>0.05$ \\
\hline Total cholesterol (mg/dl) & $195.76 \pm 43.32$ & $189.22 \pm 36.80$ & $>0.05$ \\
\hline Trigliserides (mg/dl) & $152.70 \pm 99.58$ & $150.71 \pm 58.88$ & $>0.05$ \\
\hline LDL (mg/dl) & $124.47 \pm 37.23$ & $189.22 \pm 36.80$ & $>0.05$ \\
\hline $\operatorname{HDL}(\mathrm{mg} / \mathrm{dl})$ & $42.77 \pm 10.87$ & $48.41 \pm 12.53$ & $>0.05$ \\
\hline Fasting insulin $(\mu \mathrm{IU} / \mathrm{ml})$ & $11.10 \pm 4.89$ & $12.17 \pm 4.30$ & $>0.05$ \\
\hline Postprandial insulin $(\mu \mathrm{IU} / \mathrm{ml})$ & $33.33 \pm 24.82$ & $59.96 \pm 43.40$ & $<0.05^{*}$ \\
\hline Cortisol $(\mu \mathrm{g} / \mathrm{dl})$ & $13.71 \pm 5.72$ & $13.69 \pm 8.84$ & $>0.05$ \\
\hline ACTH $(\mathrm{pg} / \mathrm{ml})$ & $21.21 \pm 11.02$ & $24.71 \pm 12.54$ & $>0.05$ \\
\hline $\mathrm{GH}(\mathrm{ng} / \mathrm{ml})$ & $1.09 \pm 1.54$ & $0.95 \pm 1.43$ & $>0.05$ \\
\hline TSH $(\mu \mathrm{IU} / \mathrm{ml})$ & $2.32 \pm 2.34$ & $1.93 \pm 1.13$ & $>0.05$ \\
\hline FT3 $(\mathrm{pg} / \mathrm{ml})$ & $2.51 \pm 0.89$ & $2.58 \pm 0.58$ & $>0.05$ \\
\hline FT4(ng/dl) & $1.00 \pm 0.31$ & $0.95 \pm 0.27$ & $>0.05$ \\
\hline Anti-microsomal antibody (IU/ml) & $32.42 \pm 36.64$ & $52.26 \pm 71.63$ & $<0.05^{*}$ \\
\hline Anti-throglobulin antibody (IU/ml) & $75.94 \pm 196.68$ & $42.71 \pm 128.57$ & $>0.05$ \\
\hline Thyroglobulin (ng/ml) & $37.45 \pm 64.76$ & $16.55 \pm 20.62$ & $<0.05^{*}$ \\
\hline $\mathrm{FSH}(\mathrm{mIU} / \mathrm{ml})$ & $47.65 \pm 62.74$ & $21.20 \pm 22.49$ & $<0.01 * *$ \\
\hline $\mathrm{LH}(\mathrm{mIU} / \mathrm{ml})$ & $19.43 \pm 19.85$ & $9.96 \pm 7.98$ & $<0.001^{* * *}$ \\
\hline $\mathrm{E} 2(\mathrm{Pg} / \mathrm{ml})$ & $92.22 \pm 69.49$ & $110.19 \pm 87.43$ & $>0.05$ \\
\hline SHBG $(\mathrm{nmol} / \mathrm{l})$ & $54.31 \pm 37.86$ & $49.28 \pm 38.03$ & $>0.05$ \\
\hline Total Testosterone $(\mathrm{mg} / \mathrm{ml})$ & $58.28 \pm 27.01$ & $69.49 \pm 31.59$ & $>0.05$ \\
\hline DHEAS (mg/dl) & $117.17 \pm 61.58$ & $124.60 \pm 56.45$ & $>0.05$ \\
\hline PRL (ng/ml) & $15.68 \pm 10.31$ & $17.80 \pm 10.56$ & $>0.05$ \\
\hline PTH $(\mathrm{pg} / \mathrm{l})$ & $63.98 \pm 25.10$ & $54.02 \pm 26.03$ & $>0.05$ \\
\hline Systolic blood pressure $(\mathrm{mmHg})$ & $122.96 \pm 16.12$ & $120.89 \pm 20.27$ & $>0.05$ \\
\hline Diastolic blood pressure $(\mathrm{mmHg})$ & $81.85 \pm 10.01$ & $78.92 \pm 12.57$ & $>0.05$ \\
\hline GGT (U/l) & $18.32 \pm 9.50$ & $26.00 \pm 16.68$ & $<0.05^{*}$ \\
\hline Uric acid $(\mathrm{mg} / \mathrm{dl})$ & $4.21 \pm 1.10$ & $4.18 \pm 1.32$ & $>0.05$ \\
\hline HOMA & $2.83 \pm 1.27$ & $2.88 \pm 1.09$ & $>0.05$ \\
\hline
\end{tabular}

REFERENCES

1. World Health Organization. (2012) Diabetes. Fact Sheet number 312.

2. HAPO Study Cooperative Research Group, Metzger BE, Lowe LP, Dyer AR, Trimble ER, et al. (2008) Hyperglycemia and adverse pregnancy outcomes. N Engl J Med 358: 1991-2002.

3. Landon MB, Mele L, Spong CY, Carpenter MW, Ramin SM, et al. (2011) The relationship between maternal glycemia and perinatal outcome. Obstet Gynecol 117: 218-224.

4. Metzger BE, Cho NH, Roston SM \& Radvany R. Pre-pregnancy weight and antepartum insulin secretion predict glucose tolerance five years after gestational diabetes mellitus. Diabetes Care $1993 \quad 16 \quad 1598-1605$. (doi:10.2337/diacare.16.12.1598)

5. Kaufmann RC, Schleyhahn FT, Huffman DG \& Amankwah KS. Gestational diabetes diagnostic criteria: long-term maternal follow-up. American Journal of Obstetrics and Gynecology 1995172 621-625. (doi:10.1016/0002-9378(95)90582$0)$

6. Kim C, Berger DK \& Chamany S. Recurrence of gestational diabetes mellitus: a systematic review. Diabetes Care 200730 1314-1319.(doi:10.2337/dc06-2517)

7. Ryan AS, McLenithan JC, Zietowski GM, Accelerated metabolic susceptibility to type 2 diabetes in older women with a history of gestational diabetes. Endocrine Connections (2013) 2, 79-86

8. Lawrence JM, Black MH, Hsu J-W, Chen W, Sacks DA. Prevalence and Timing of Postpartum Glucose Testing and Sustained Glucose Dysregulation After Gestational Diabetes Mellitus. Diabetes Care. March 1, 2010 2010;33(3):569-576.

9. Getahun D, Fassett MJ, Jacobsen SJ. Gestational diabetes: risk of recurrence in subsequent pregnancies. Am J Obstet Gynecol. Nov 2010;203(5):467 e461-466. 